BASINDO : Jurnal Kajian Bahasa, Sastra Indonesia, dan Pembelajarannya

Volume 2 Nomor 1, 2018

Journal homepage : http://journal2.um.ac.id/index.php/basindo

\title{
MODEL PEMBELAJARAN CIPRO (CITIZEN PROSEDUR) SEBAGAI ALTERNATIF PENGAJARAN TEKS PROSEDUR DALAM MATAPELAJARAN BAHASA INDONESIA
}

\author{
Emy Rizta Kusuma* \\ Magister Pendidikan Bahasa Indonesia, Pascasarjana Universitasn Negeri Malang, Indonesia
}

\section{A R T I C LE IN F O}

Keyword:

Model CIPRO,

teks prosedur,

pembelajaran bahasa

Indonesia

\begin{abstract}
A B S T R A C T
Model pembelajaran merupakan salah satu unsur terpenting dalam suatu kegiatan pembelajaran. Dengan pengunaan model pembelajaran yang tepat, peserta didik tidak hanya berhasil dalam memahami materi yang diajarkan, tetapi minat belajar mereka juga secara tidak langsung akan meningkat. Jika minat belajar pserta didik meningkat, tentunya juga akan terwujudkan situasi belajar yang menyenangkan. CIPRO atau Citizen Prosedur merupakan salah satu model pembelajaran yang dikembangkan dari metode Partisiatori. Metode Partisiatori merupakan metode pembelajaran yang melatih peserta untuk berpikir mandiri, sedangkan model CIPRO yang dikembangkan melatih peserta didik untuk berpikir mandiri dan percaya diri terhadap kemampuan yang dimilikinya. Dari hasil penelitian yang dilakukan, model ini berhasil meningkatkan minat belajar peserta didik pada pengajaran teks prosedur. Selain itu, model ini juga mampu meningkatkan pemahaman peserta didik terkait pengajaran teks prosedur..
\end{abstract}

\section{PENDAHULUAN}

Model pembelajaran diartikan sebagai prosedur sistematis dalam mengorganisasikan pengalaman belajar untuk mencapai tujuan belajar. Model pembelajaran merupakan salah satu unsur terpenting dalam suatu kegiatan pembelajaran. Dengan pengunaan model pembelajaran yang tepat, peserta didik tidak hanya berhasil dalam memahami materi yang diajarkan, tetapi minat belajar mereka juga secara tidak langsung akan meningkat(Shinta, Chamalah, \& Arsanti, 2018).

Slavin (2010:36) menjelaskan bahwa model pembelajaran adalah suatu acuan kepada suatu pendekatan pembelajaran termasuk tujuannya, sintaksnya, lingkungannya, dan sistem pengelolaanya. Sejalan dengan Slavin, Trianto (2009:28) menjelaskan bahwa model pembelajaran merupakan pendekatan yang luas dan menyeluruh serta dapat diklasifikasikan berdasarkan tujuan pembelajarannya, sintaks (pola urutannya), dan sifat lingkungan belajarnya. Dari penjelasn tersebut, dapat disimpulkan bahwa model pembelajaran yang digunakan dalam kegiatan pembelajaran dapat dikembangkan dan disesuaikan dengan tujuan pembelajaran yang ingin dicapai.

Fakta penerapan model pembelajaran yang digunakan di sekolah lebih menekankan agar peserta didik mendapatkan nilai yang baik. Guru mengajarkan peserta didik untuk tahu, tetapi tidak mengajarkan peserta didik untuk memahami. Padahal aspek terpenting ketika pembelajaran adalah peserta didik memahami apa yang diajarkan oleh guru. Ketika peserta didik memahami, maka peserta didik akan lebih mudah mengerti. Aspek penting inilah yang sering dilupakan oleh guru. Oleh sebab itu, dalam menentukan model pembelajaran yang digunakan, guru juga perlu memperhatian pencapaian kompetensi yang menjadi tujuan akhir dalam pembelajaran.

\footnotetext{
" Corresponding author.

E-mail addresses: emy.kusuma01@gmail.com (Emy Rizta Kusuma)
}

ISSN : 2579-3799 (Online) - BASINDO : Jurnal Kajian Bahasa, Sastra Indonesia, dan Pembelajarannya is licensed under Creative Commons Attribution-ShareAlike 4.0 International License (http://creativecommons.org/licenses/BY/4.0/).

44 | BASINDO : Jurnal Kajian Bahasa, Sastra Indonesia, dan Pembelajarannya 
Model pembelajaran yang digunakan dalam mata pelajaran bahasa Indonesia, khususnya materi teks prosedur adalah model pembelajaran CIPRO (Citizen Prosedur). Model pembelajaran ini mengajarkan peserta didik untuk aktif mendapatkan dan mengolah informasi terkait struktur dan ciri kebahasan teks prosedur yang dipelajari. Model ini juga didukung dengan teori pembelajaran konstruktivisme yang mengajarkan peserta didik untuk mengontruksi pengalaman dan pemahamannya secara mandiri. Selain itu, model ini juga didukung dengan pendekatan dan metode pembelajaran bahasa yang pernah dan berhasil digunakan dalam pembalajaran bahasa.

Tujuan dari penerapan model pemebelajaran CIPRO (Citizen Prosedur)pada dasarnya sebagai salah satu alternatif model pembelajaran bahasa yang nantinya dapat dimanfaatkan oleh guru bahasa Indonesia dalam kegiatan belajar mengajar. Tujuan tersebut sejalan dengan pendapat Soekamto dan Winataputra (1995:78) yang mendefinisikan model pembelajaran sebagai kerangka konseptual yang menggambarkan prosedur yang sistematis dalam mengorganisasikan pengalaman belajar bagi para peserta didik untuk mencapai tujuan pembelajaran dan berfungsi sebagai pedoman bagi para perancang pembelajaran dan para pengajar dalam merencanakan dan melaksanakan aktivitas belajar mengajar. Oleh sebab itu, guru tidak boleh sembarangan dalam menentukan model pembelajaran yang akan digunakan dalam kegiatan pembelajaran.

\section{HAKIKAT MODEL PEMBELAJARAN CIPRO (CITIZEN PROSEDUR) Pengertian Model Pembelajaran CIPRO (Citizen Prosedur)}

Model pembelajaran Citizen Prosedur terinsiprasi dari rubrik Citizen Reporter yang ada pada Harian Surya. Rubrik tersebut berisi infromasi-informasi menarik yang ditulis oleh orang yang tidak memiliki ikatan kerja di Harian Surya. Rubrik ini memberikan wadah bagi setiap orang yang ingin menginformasikan hasil pengalaman, hasil kegiatan, serta informasi-infromasi menarik sesuai pengetahuan pribadinya. Dari situlah, model pembelajaran ini dikembangkan.

Tujuan dari modifikasi rubrik Citizen Report Harian Surya menjadi sebuah model pembelajaran adalah untuk melatih peserta didik mengembangkan pengetahuan tentang teks prosedur dengan pengalaman langsung mengamati, mengidentifikasi, dan menelaah teks prosedur yang telah disediakan oleh guru. Setelah peserta didik mengamati, mengidentifikasi, dan menelaah struktur dan ciri kebahasaan teks prosedur, selanjutnya peserta didik diminta menuliskan hal-hal yang mereka pahami dari kegiatan tersebut secara individu. Setelah itu, peserta didik mendisikusikan hasil telaah tersebut untuk dijadikan ringkasan atau rangkuman yang kemudian dipresentasikan di depan kelas.

Dari penjelasan di atas dapat disimpulkan bahawa model pembelajaran Citizen Prosedur merupakan sebuah model pembelajaran yang mengarahkan peserta didik untuk dapat berperan aktif dalam menelaah struktur dan ciri kebahasaan teks prosedur sesuai dengan pengalaman dan pemahaman langsung dari masing-masing peserta didik. Model ini tidak semata-mata tercipta begitu saja, terdapat landasan teori yang memperkuat penerapan model pembelajaran ini dalam kegiatan pembelajaran. Berikut landasan teori yang melatarbelakangi model pembelajaran CIPRO (Citizen Prosedur).

\section{Landasan Teori Model Pembelajaran CIPRO (Citizen Prosedur)}

Model Pembelajaran CIPRO (Citizen Prosedur)dilatarbelakangi oleh beberapa landasan teori. Berikut landasan teori yang digunakan dalam model pembelajaran CIPRO (Citizen Prosedur).

\section{Teori Pembelajaran Konstruktivisme dalam Penerapan Model Pembelajaran CIPRO (Citizen Prosedur)}

Kontruktivisme adalah sebuah filosofi pembelajaran yang dilandasi premis bahwa dengan merefleksikan pengalaman seseorang, maka orang itu dapat mengonstruksi pengetahuan pemahaman tentang dunia tempat hidup. Teori belajar tersebut semata-mata sebagai suatu proses pengaturan model mental seorang untuk mengakomodasi pengalaman-pengalaman baru (Suyono \& Hariyanto, 2012).

Ada tiga penekanan dalam teori belajar konstruktivisme, yakni (1) peran aktif peserta didik dalam mengonstruksi pengetahuan secara bermakna, (2) pentinya membuat kaitan antara gagasan dalam pengonstruksian secara bermakna, dan (3) mengaitkan antara gagasan dengan informasi baru yang diterima. Selain itu, terdapat prinsip yang dikemukakan oleh Wheatley (dalam Kulsum, 2011), yaitu (1) pengetahuan tidak dapat ditemukan secara pasif, tetapi secara aktif oleh struktur kognitif peserta didik, dan (2) fungsi kognisi bersifat adaptif dan membantu pengorganisasian melalui pengalaman nyata melalui pengalaman anak.

Pembelajaran yang mengacu pada teori belajar konstruktivisme lebih memfokuskan pada kesuksesan dalam mengorganisasikan pengalaman mereka, bukan kepatuhan peserta didik dalam merefleksikan hal yang ditelah diperintahkan dan dilakukan oleh guru. Dengan kata lain, peserta lebih diutamakan lebih mengonstruksi sendiri pengetahuan mereka melalui asimilasi dan akomodasi. Oleh sebab itu, teori belajar ini sesuai dengan model pembelajaran CIPRO yang melatih peserta didik untuk menelaah 
struktur dan ciri kebahasaan teks prosedur secara mandiri sesuai dengan pengalaman dan pengetahuan yang mereka miliki terkait teks prosedur. Jika peserta didik mampu mengonstruk pengalamannya sendiri, maka ilmu dan pemahaman mereka terkait teks prosedur akan lebih bermakna, sebab mereka belajar memperoleh ilmu dan pemahaman tersebut secara mandiri.

\section{Pendekatan Saintifik dalam Model Pembelajaran CIPRO (Citizen Prosedur)}

Pembelajaran dengan pendekatan ilmiah melibatkan kemampuan berpikir tingkat tinggi. Ketika melaksanakan kegiatan mengamati, peserta didik melakukan identifikasi untuk menemukan masalah. Setelah masalah ditemukan, peserta didik merumuskan masalah melalui pertanyaan-pertanyaan yang diajukan, kemudian pertanyaan itu ditemukan jawabannya dengan mengumpulkan data dengan berbagai teknik, menganalisis data, menarik kesimpulan, dan mengomunikasikan temuannya. Keseluruhan tahapan tersebut melibatkan keterampilah berpikir tingkat dasar sampai tingkat tinggi, dimulai dari mengidentifikasi, mengingat, mengorganisasi, menganalisis, menyimpulkan, dan mengevaluasi (Priyatni, 2014).

Model pembelajaran CIPRO mengikuti prinsip dasar dari pendekatan saintifik yang meliputi mengamati, menanya, mengumpulkan informasi, menalar, dan mengkomunikasikan. Proses 5M dilakukan pada bagian inti pembelajaran. Proses mengamati, menanya, dan mengumpulkan informasi dilakukan ketika peserta didik berperan menjadi citizen telaah teks prosedur. Selanjutnya, proses Proses menalar terjadi ketika peserta didik mencoba untuk mengidentifikasi dan menganalisis struktur dan ciri kebahasaan teks prosedur. Terakhir, proses mengkomunikasikan terjadi ketika peserta didik menyampaikan hasil diskusinya ketika menelaah teks prosedur.

\section{Metode Partisiatori dalam Model Pembelajaran CIPRO (Citizen Prosedur)}

Metode pembelajaran partisipatori merupakan metode pembelajaran yang memberikan kebebasan kepada peserta didik untuk berekspresi sesuai minat dan bakatnya dalam pembelajaran. Dalam model pembelajaran partisipatori, peserta didik menempatkan dirinya dalam suatu peran yang aktif dalam pembelajaran (Ajiboye \& Ajitoni, 2008). Peserta didik memiliki keleluasaan yang sangat besar dalam mengembangkan kemampuannya baik dalam menemukan masalah, mencari informasi, dan merekonstruksi informasi sehingga dapat digunakan untuk menyelesaikan masalah. Penjelasan tersebut sesuai dengan tujuan dan pelaksanaan model pembelajaran CIPRO yang menempatkan peserta didik langsung terlibat dalam praktek menelaah struktur dan ciri kebahasaan teks prosedur.

Ciri khas model pembelajaran ini adalah pembelajaran berpusat pada peserta didik.Artinya peserta didiklah yang berperan aktif dalam kegiatan pembelajaran. Tugas guru pada metode ini adalah mengarahkan, menjadi fasilitator, dan mediator bagi peserta didik pada saat peserta didik mengalami kesulitan dalam merekonstruksi informasi terkait materi pembelajaran (Barak \& Shakhman, 2008).

\section{Langkah-langkah Model Pembelajaran CIPRO (Citizen Prosedur)}

Model pembelajaran CIPRO (Citizen Prosedur) ini difokuskan pada KD 3.6, yakni menelaah struktur dan aspek kebahasaan teks prosedur. Penjelasan tahap-tahap pelaksanaan model pembelajaranCIPRO (Citizen Prosedur) dipaparkan sebagai berikut.

1) Guru melakukan apersepsi pada peserta didik dengan menanyakan cara mereka sampai di sekolah. Setelah itu guru menstimulus peserta didikdengan video berjudul langkah-langkah membuat bunga kertas. Ketika menstimulus ini peserta didik berusaha untuk menanya dan mengumpulkan informasi sebanyak-banyaknya pada guru. Secara terintegrasi guru juga menyampaikan materi tentang teks prosedur.

2) Guru membagi peserta didik ke dalam beberapa kelompok. Setelah membagi kelompok, guru menyediakan teks prosedur yang akan ditelaah. Secara individu peserta didik diminta untuk mengamati, mengidentifikasi, dan menelaah teks prosedur yang telah disediakan. Pada saat ini, peserta didik menerapkan citizen prosedur yang tujuan akhirnya adalah hasil telaah struktur dan ciri kebahasaan teks prosedur.

3) Setelah masing-masing peserta didik mengamati, mengidentifikasi, dan menelaah teks prosedur,peserta didik ditugaskan untuk mengemukakan hasil pengamatannya dalam kelompoknya. Ketika semua peserta didik selesai mengemukakan (mengomunikasikan) teks prosedur yang telah diamati, diidentifikasi, dan ditelaah, selanjutnya kelompok peserta didik membuat kesimpulan dan ringkasan dari hasil diskusi kelompok.

4) Setelah kelompok selesai membuat kesimpulan dan ringkasan, kegiatan diarahkan untuk mempresentasikan hasil diskusi kelompoknya di hadapan kelompok lain. Terakhir, hasil tulisan peserta didik diunggah di internet agar dapat dibaca orang banyak. 


\section{Kelebihan dan Kekurangan Model Pembelajaran CIPRO (Citizen Prosedur)}

Setiap model pembelajaran tentu memiliki kelebihan dan kekurang ketika diterapkan dalam kegiatan pembelajaran. Kelebihan dan kelemahan model pembelajaran CIPRO (Citizen Prosedur)adalah berikut ini.

a. Kelebihan model CIPRO (Citizen Prosedur)ini adalah (1) bisa menciptakan suasana yang rileks, dan menyenangkan ketika pembelajaran, (2) memotivasi peserta didik untuk bisa mengekspresikan pengalaman yang belangsung ketika pembelajaran berlangsung, (3) mendorong peserta didik untuk bisa berpikir secara kritis, (4) memotivasi guru untuk bisa menciptakan model-model pembelajaran lain yang kreatif, inovatif dan menyenangkan, dan (5) modelCIPRO (Citizen Prosedur)ini tidak hanya bisa digunakan untuk pembelajaran teks prosedur saja, tetapi juga bisa digunakan untuk teks-teks lainnya.

b. Kelemahan model CIPRO (Citizen Prosedur) ini adalah (1) karena suasana santai, bisa jadi ketika pembelajaran peserta didik juga terlalu santai, dan (2) guru harus bisa mengkoordinasi peserta didik untuk tetap fokus dan terarah ketika melaksanakan pembelajaran, dan (3) model ini hanya bisa diterapkan di sekolah yang fasilitas untuk penunjang kegiatan pembelajaran memadai.

\section{PENUTUP}

Materi ajar teks prosedur bukan merupakaan materi yang mudah dalam pembelajaran bahasa. Tujuan pengajaran teks prosedur tidak hanya sekedar mengajarkan langkah-langkah membuat dan melakukan seuatu, tetapi lebih lanjut peserta didik juga diajarkan cara untuk memahami kebahasaan dan informasi yang tekandung dalam teks prosedur. Agar tujuan pembelajaran dapat terlaksana dengan baik maka diperlukan model pembelajaran yang tepat untuk digunakan dalam pengajaran teks prsedur.

Model pembelajaran CIPRO (Citizen Prosedur) mengajarkan peserta didik untuk aktif mendapatkan dan mengolah informasi terkait struktur dan ciri kebahasan teks prosedur yang dipelajari. Model ini juga didukung dengan teori pembelajaran konstruktivisme yang mengajarkan peserta didik untuk mengontruksi pengalaman dan pemahamannya secara mandiri. Selain itu, model ini juga didukung dengan pendekatan dan metode pembelajaran bahasa yang pernah dan berhasil digunakan dalam pembalajaran bahasa.

\section{DAFTAR RUJUKAN}

Ajiboye J. O., Ajitoni S. O. (2008). Effects of full and quasi-participatory learning strategies on Nigerian senior secondary students' environmental knowledge: Implication for classroom practice. International Journal of Environmental and Science Education, 3, 58-66. (Online) http://www.Google Scholar.com, diakses tanggal 25 April 2017.

Indrawati dan Setiawan, W. (2009). Modul Pembelajaran Aktif, Kreatif, Efektif, dan Menyenangkan. Jakarta: PPPPTKIPA.

Kulsum, U. (2011). Implementasi Pendidikan Karakter Berbasir PAIKEM (Sebuah Paradigma Baru Pendidikan di Indonesia). Surabaya: Gena Pratama Pustaka.

Shinta, Y. D., Chamalah, E., \& Arsanti, M. (2018). Penerapan Model Pembelajaran Berdasarkan Masalah dan Media Video Animasi Peristiwa Sosial Bermuatan Pendidikan Multikultural untuk Meningkatkan Keterampilan Menyusun Teks Eksplanasi. BASINDO: Jurnal Kajian Bahasa, Sastra Indonesia, dan Pembelajarannya, 1(2), 59-71.

Priyatni, E.T. (2014). Desain Pembelajaran Bahasa Indonesia Dalam Kurikulum 2013. Jakarta: Bumi Aksara.

Rusman. (2011). Model-Model Pembelajaran. Jakarta: Rajawali Pers.

Slavin, R.E. (2010). Cooperative Learning Teori, Riset dan Praktik. Bandung: Nusa Media.

Soekamto, T. dan Winataputra, U.S. (1995). Strategi Belajar Mengajar. Jakarta: Rineka Cipta.

Suyono \& Hariyanto. (2012). Belajar dan Pembelajaran: Teori dan Konsep Dasar: Bandung: Remaja Rosdakarya

Trianto. (2009). Mendesain Model Pembelajaran Inovatif-Progresif. Jakarta: Kencana Prenada Group. 